\title{
Author Correction: Hemisphere-asymmetric tropical cyclones response to anthropogenic aerosol forcing
}

Jian Cao, Haikun Zhao, Bin Wang \& Liguang Wu

Correction to: Nature Communications https://doi.org/10.1038/s41467-021-27030-z, published online 22 November 2021.

The original version of this Article contained an error in ref. 5, which was incorrectly given with the wrong first author name as: Carmago, S. J. The correct form of ref. 5 is: Camargo, S. J. Global and regional aspects of tropical cyclone activity in the CMIP5 models. J. Clim. 26, 9880-9902 (2013).

This has been corrected in the PDF and HTML versions of the Article.

Published online: 07 January 2022

(c) (i) Open Access This article is licensed under a Creative Commons Attribution 4.0 International License, which permits use, sharing, adaptation, distribution and (C) reproduction in any medium or format, as long as you give appropriate credit to the original author(s) and the source, provide a link to the Creative Commons license, and indicate if changes were made. The images or other third party material in this article are included in the article's Creative Commons license, unless indicated otherwise in a credit line to the material. If material is not included in the article's Creative Commons license and your intended use is not permitted by statutory regulation or exceeds the permitted use, you will need to obtain permission directly from the copyright holder. To view a copy of this license, visit http://creativecommons.org/licenses/by/4.0/.

(c) The Author(s) 2022 